\title{
Deforestation rate is falling
}

\section{São Paulo}

BraziLIANS are burning their rain forest less. The latest figures on deforestation in Amazonia show that the felling and burning of trees diminished by 27 per cent from 1989 to 1990. The new data collected by the Institute of Space Research (INPE) refer to deforestation from August 1989 to August 1990 in the 4.6-million-square-kilometre region parts of nine states in the north of Brazil.

In the 1989 study, INPE declared that 17,871 square kilometres of forest had disappeared. The new study puts the figure at 13,818 square kilometres. Data were provided by the Thematic Mapper instruments aboard the Landsat 5 satellite.

Previous studies by the Space Institute had a greater margin of error -10 per cent - because the process of adding up the data was not automated. More advanced methods of processing the data made the margin of error fall to 5 per cent, according to the director of the institute, Márcio Nogueria Barbosa. But although in the past INPE has been forced to issue statements correcting data it had released, the biggest problems with some of the studies have been political. In the government of president José Sarney (1985-90), INPE tried to present the data in the most favourable way, 'making it up' to show small deforestation percentages. Sarney even deknown as Legal Amazonia, which comprises clared to Newsweek, before INPE's studies

were released, that only 5 per cent of Amazonia was destroyed, when the actual figure is close to 10 per cent. INPE obediently said that the percentage was only 5 per cent, and later had to correct it and give further explanations.

President Fernando Collor de Mello tried to throw off the image of Brazil as environmental villain. The new figures, says José Goldemberg, the Secretary of Science and Technology, would make it easier for Brazil to deal with international institutions. He thinks that the smaller rate is a consequence both of the increase of fiscalization and the cut of subsidies for farming in Amazonia.

Even though the overall rate has decreased, there is cause for concern in some specific areas. Rondonia, the worst affected state in recent years, showed a slight increase in deforestation - 1,676 square kilometres against 1,441 in the previous study. The other state where deforestation increased, Amapá, has 9 per cent of its territory deforested, in Rondonia the figure is 14 per cent.

Brazilian government officials hope that this trend will continue, so that they could show the world the country's new proenvironment stance. The forum for this would be the United Nations Conference on the Environment and Development, scheduled to meet in Rio de Janeiro in 1992. Ricardo Bonalume

\section{From mine camp to laboratory}

\section{São Paulo}

BRAZIL's biggest university has received an unexpected gift: a new base for tropical research deep in the Amazonian rain forest, complete with facilities to house 2,000 people. The University of São Paulo (USP) announced last month that a Brazilian mining company is giving it a complete town, Vila Serra do Navio, in the state of Amapá, which borders French Guiana.

The company, Indústria e Comércio de Minério SA (ICOMI), obtained a government concession to mine manganese in Amapá in 1950. The concession expires in 50 years, but the manganese ran out first. So instead of simply abandoning the town for the jungle to reclaim, ICOMI offered it to the university, which gladly accepted.

The mining company said it was proud of having built a model town in the middle of the forest and did not want to see it simply disappear.

To maintain the town's infrastructure, the company spends about $\$ 3$ million a year, and ICOMI has promised to pay the university for the upkeep until the end of 1992. After that, the university must take over, but USP rector Roberto Leal Lobo e Silva Filho says it will not shift funds from the budget to pay for it. Brazil's Secretariat for Science and Technology has already

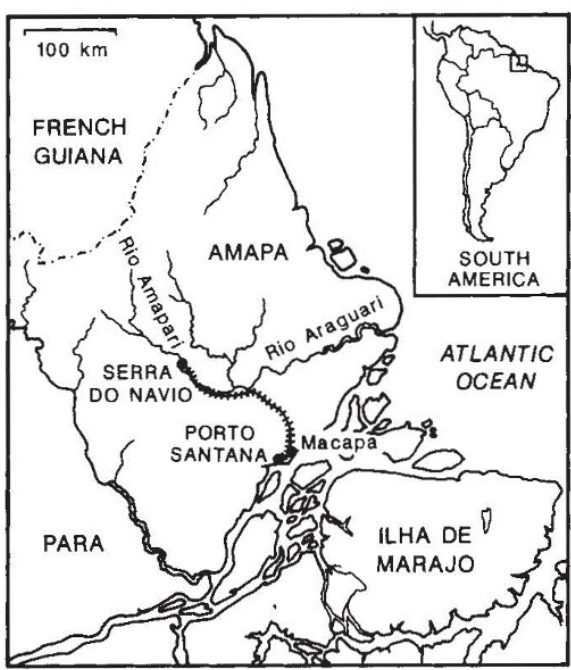

shown interest, he said, although it has not yet offered any money.

Vila Serra do Navio is $196 \mathrm{~km}$ by railroad from the Amapa coast. The town has about 500 houses, the only hospital in the area which attends to the needs of about 12,000 local inhabitants - and shopping and recreational facilities. With the miners gone, the elementary school and several other buildings will be turned into laboratories.

\section{First maternal transmission?}

\section{London}

A NEW case of bovine spongiform encephalopathy (BSE) may be the first known in which a cow was infected by its mother in utero rather than from infected feed.

Last week, pathologists from the Ministry of Agriculture Fisheries and Food (MAFF) confirmed the presence of BSE in a cow from Cheshire born in November 1988. Since the birth date was three months after the government banned the use of cattle feed containing ruminant meat and bone meal, it seems unlikely that the animal contracted BSE by that route. The cow's mother developed BSE in 1989.

John Wilesmith, who heads MAFF's BSE epidemiology team, says that his group must now examine the animal's history, to check that it was not fed accidentally with banned cattle feed. But even if confirmed, an isolated case of maternal transmission is not a cause for great alarm, Wilesmith says: maternal transmission would have to be a common occurrence significantly to lengthen the British BSE epidemic. MAFF has no plans to ban breeding from the offspring of BSE cases. Peter Aldhous

COMPUTER INDUSTRY

\section{ICL expelled from JESSI projects \\ London}

THE UK-based computer company ICL has been expelled from three projects within the Joint European Submicron Silicon Initiative (JESSI), the $\$ 5,000$ million collaboration in semiconductor research funded by European computer companies, the European Communities (EC) and EC member governments. The decision comes in response to ICL's takeover last year by the Japanese company Fujitsu - a sensitive issue for JESSI, which was set up in 1989 to help the European computer industry to compete with Japanese companies.

The ejection from JESSI follows ICL's expulsion in January from the European Information Technology Round Table, a group of 12 European computer companies that lobbies the EC and European governments to influence policy towards the industry. An ICL spokesman says that the decisions are "unfortunate, but not devastating".

ICL, never more than a minor player in JESSI, will continue to participate in two JESSI projects in computer-aided design when the companies involved decided there was no other European company to take ICL's place. ICL researchers are also still working on a number of EC projects.

Peter Aldhous 